International Journal of Current Advanced Research

ISSN: O: 2319-6475, ISSN: P: 2319 - 6505, Impact Factor: SJIF: 5.995

Available Online at www.journalijcar.org

Volume 6; Issue 4; April 2017; Page No. 3042-3044

DOI: http://dx.doi.org/10.24327/ijcar.2017.3044.0175

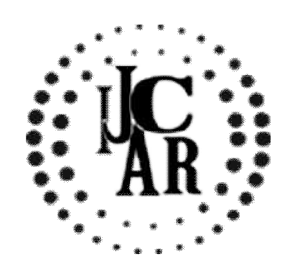

Research Article

\title{
CUSP OFCARABELLI- FREQUENCY, DISTRIBUTION, SIZE AND CLINICAL SIGNIFICANCE
}

\author{
Dhanalakshmi S and Don K. R
}

Saveetha Dental College, Chennai-600077, Tamil Nadu, India

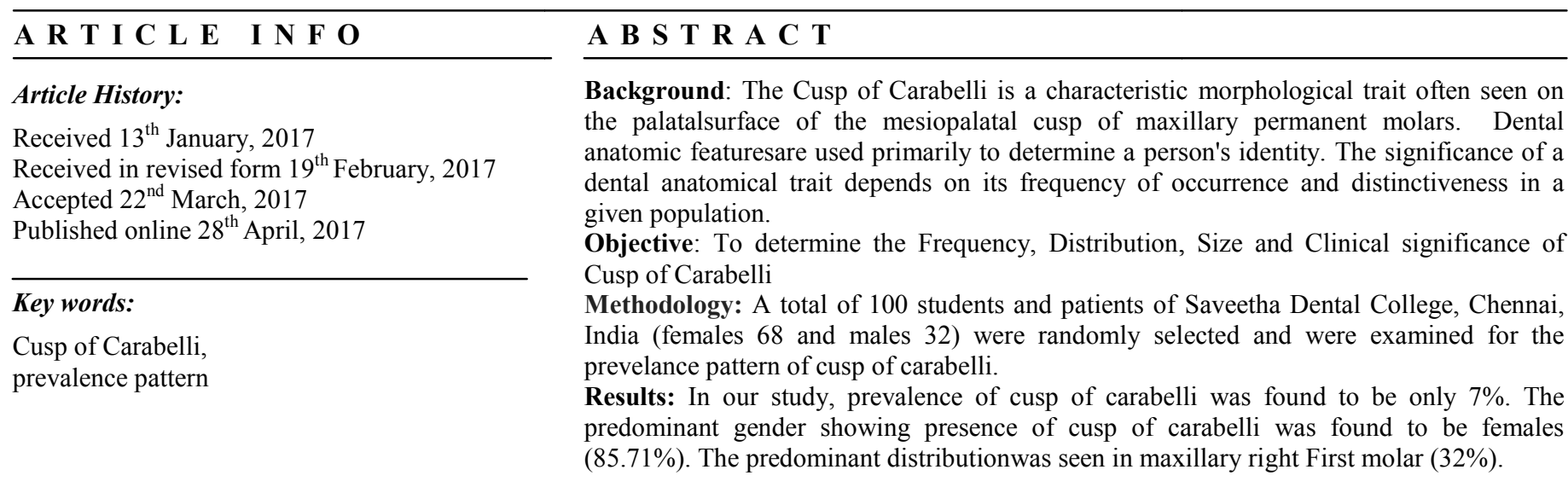

Copyright $@ 2017$ Dhanalakshmi S and Don K. R. This is an open access article distributed under the Creative Commons Attribution License,

which permits unrestricted use, distribution, and reproduction in any medium, provided the original work is properly cited.

\section{INTRODUCTION}

The cusp of Carabelli, or Carabelli's tubercle, or tuberculumanomale of Georg Carabelli is a small additional cusp at the mesiopalatal line angle of maxillary first molars. This extra cusp is usually found on the first molar, and becomes progressively less likely in the second, third molars. ${ }^{1}$ This cusp is entirely absent in some individuals and present in others in a variety of forms. In some cases, Carabelli's cusp may rival the main cusps in size. Other related forms include ridges, pits, or furrows. This additional cusp was first described in 1842 by the Hungarian Georg Carabelli (Carabelli György), the court dentist of the Austrian Emperor Franz. The cusp of Carabelli is a heritable feature. Kraus (1951) proposed that homozygosity of a gene is responsible for a pronounced tubercle, whereas the heterozygote shows slight grooves, pits, tubercles or bulge. ${ }^{1}$ Later studies showed that the development of this trait is affected by multiple genes. Carabelli's cusp is most common among Europeans (75-85\% of individuals) and rarest in Pacific Islands (35-45\%) The studies involved its prevalence, expression, size, shape, symmetry, dentition predilection, inheritability, morphogenesis and its association with fluoride and nutrients intake. If present, the level of expression of CT varies from a mere pit or groove to a well developed cusp. ${ }^{2}$ Studies claim that there is variation in the prevalence pattern of cusp of carabelli, particularly regional variations.

\section{*Corresponding author: Dhanalakshmi S}

Saveetha Dental College, Chennai-600077, Tamil Nadu, India
So this study was done to assess the Frequency, Distribution, and Size and Clinical significance of Cusp of Carabelli in South Indian population.

\section{MATERIALS AND METHODOLOGY}

A total of 100 students and patients of Saveetha Dental College, Chennai, India (females 68 and males 32) were randomly selected and were examined for the presence of cusp of carabelli. The examinations were carried out using a dental mouth mirror and dental explorer.

\section{Inclusion Criteria}

1. The teeth $16 / 26$ and $17 / 27$ free of dental caries were included.

2. The teeth $16 / 26$ and $17 / 27$ which did not have restoration were included.

3. The Indian nationals were only included.

\section{Exclusion Criteria}

1. The teeth $16 / 26$ and $17 / 27$ which had dental caries were excluded

2. The teeth $16 / 26$ and $17 / 27$ which had restoration that made observations unreliable were excluded.

\section{RESULTS}

Table 1 shows general characteristics of study population. In our study out of 100 participants $68(68 \%)$ were females and $32(32 \%)$ were males. 
Table 1General characteristics of study population

\begin{tabular}{ccc}
\hline S.No & Gender & $\begin{array}{c}\text { No of } \\
\text { participants }\end{array}$ \\
\hline 1 & Males & $\mathbf{3 2 ( 3 2 \% )}$ \\
2 & Females & $\mathbf{6 8 ( 6 8 \% )}$ \\
\hline
\end{tabular}

Table 2 shows the prevalence of cusp of carabelli. Out of 400 tooth samples only $28(7 \%)$ showed cusp of carabelli. Remaining 372(93\%) showed absence of cusp of carabelli.

Table 2 Prevalence of cusp of carabelli

\begin{tabular}{ccc}
\hline S.No. & $\begin{array}{c}\text { Prevalence of } \\
\text { cusp of carabelli }\end{array}$ & No. (\%) \\
\hline 1 & Presence & $\mathbf{2 8}(7 \%)$ \\
2 & Absence & $\mathbf{3 7 2 ( 9 3 \% )}$ \\
\hline
\end{tabular}

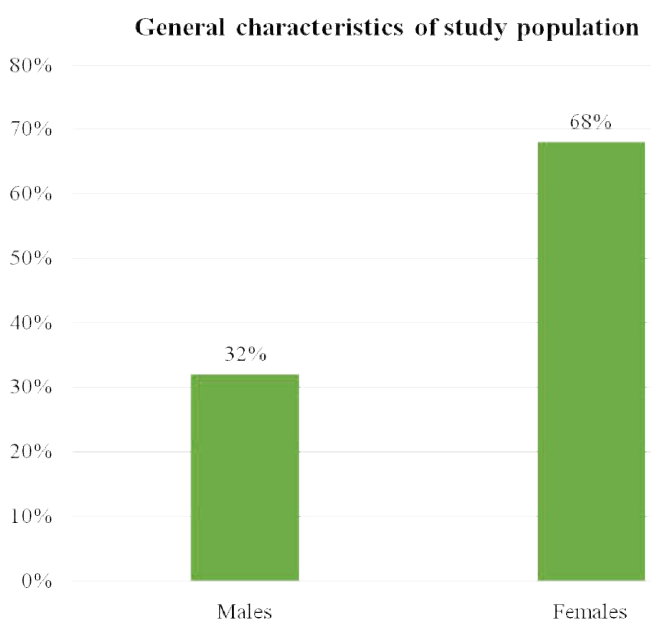

Graph 1 graph showing the general characteristics of study population. Prevalance of cusp of carabelli

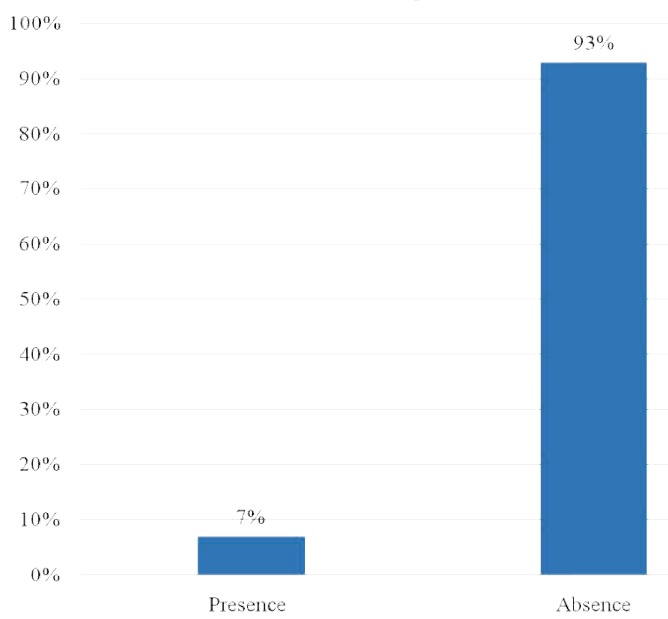

Graph 2 graph showing the prevalence of cusp of carabelli.

Table 3 shows the distribution of cusp of carabelli.Unilateral presence of cusp of Carabelli in maxillary right first molar accounted for $32 \%$. Unilateral presence of cusp of carabelliin maxillary right second molar accounted for $0 \%$.Unilateral presence of cusp of Carabelli in maxillary left first and second molar accounted for $29 \%$ and $4 \%$ respectively. Bilateral presence of cusp of carabelli in maxillary right first and second molar accounted for $0 \%$.
Table 3 Distribution of cusp of carabelli

\begin{tabular}{ccc}
\hline S.No & $\begin{array}{c}\text { Teeth } \\
\text { No }\end{array}$ & Distribution \\
\hline 1 & 16 & $9(32 \%)$ \\
2 & 17 & 0 \\
3 & 26 & $8(29 \%)$ \\
4 & 27 & $1(4 \%)$ \\
5 & $16 / 17$ & 0 \\
6 & $26 / 27$ & 0 \\
7 & $16 / 26$ & $3(10 \%)$ \\
8 & $17 / 27$ & 0 \\
9 & $16 / 27$ & $1(4 \%)$ \\
10 & $17 / 26$ & $1(4 \%)$ \\
\hline
\end{tabular}

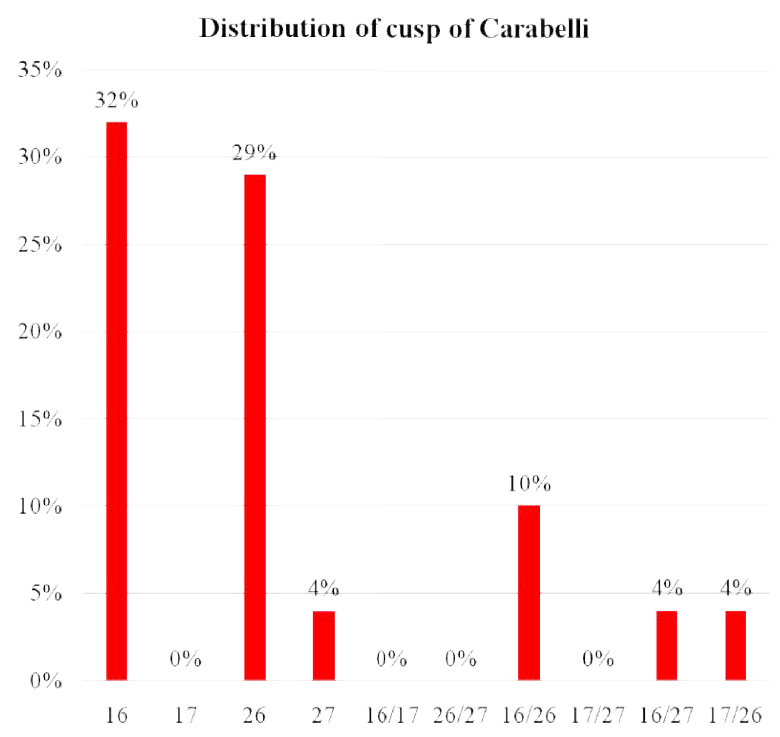

Graph 3 graph showing the distribution of cusp of carabelli.

Table 4 Gender distribution of cusp of carabelli

\begin{tabular}{ccc}
\hline S.No. & Gender & Prevalance\% \\
\hline 1 & Males & $14.29 \%$ \\
2 & Females & $85.71 \%$ \\
\hline
\end{tabular}

\section{Gender distribution}

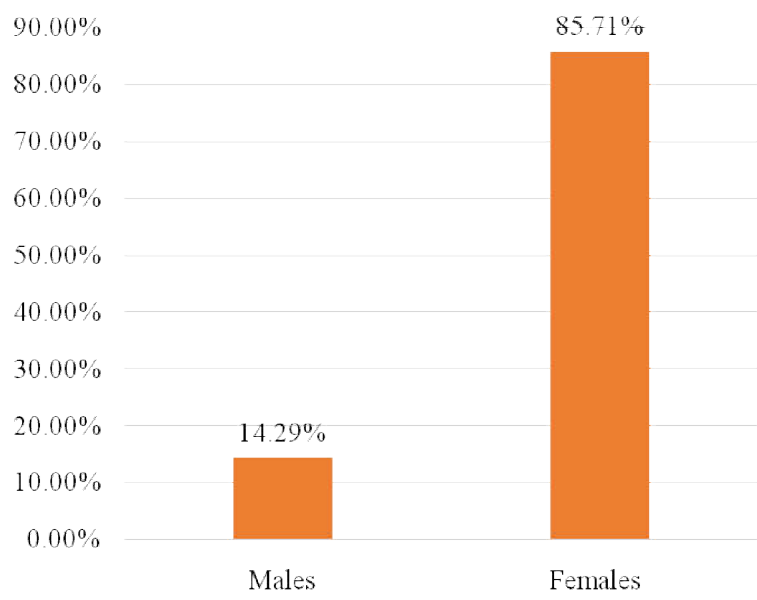

Graph 4 graph showing the gender distribution of cusp of carabelli.

Bilateral presence of cusp of carabelli in maxillary Left first and second molar accounted for $0 \%$. Bilateral presence of cusp of carabelli in maxillary right and left first molar accounted for $10 \%$. Bilateral presence of cusp of carabelli in maxillary right and left second molar accounted for $0 \%$. 
Bilateral presence of cusp of carabelli in maxillary right fist molar and leftsecond molar accounted for 4\%. Bilateral presence of cusp of carabelli in maxillary right second molar and left first molar accounted for $4 \%$.

Table 4 shows the prevalence of individuals showing the cusp according to sex. Out of 400 samples, 28 showed presence of cusp of carabelli in which $4(14.29 \%)$ were males and 24 $(85.71 \%)$ were females.

\section{DISCUSSION}

Dental anatomic features are used primarily to determine a person's identity, origin and gender. The significance of a dental anatomical trait depends on its frequency of occurrence and distinctiveness in a given population. The Cusp of Carabelli is a characteristic morphological trait often seen on the palatal surface of the mesiopalatal cusp of maxillary permanent molars and maxillary second deciduous molars.

The fifth cusp in the upper molars or Carabelli trait is the most commonly occurring dental morphological characteristicthat is useful in forensic, anthropological and ethnic studies. It has no established etiology, nor known function or clinical importance. The studies involved its prevalence, expression, size, shape, symmetry, dentition predilection, inheritability, morphogenesis and its association with fluoride and nutrients intake. If present, the level of expression of CT varies from a mere pit or groove to a well developed cusp. It has been given innumerable names:trait of Carabelli, tubercle of Carabelli, molar tubercle, enamel elevation, fifth cusp, accessory cusp, mesiopalatal prominence and tuberculumanomalum.

Table 5 shows the comparison of present study with other studies.

Table 5 comparison of present studies with other studies

\begin{tabular}{ccccc}
\hline S.No & & Prevalence & $\begin{array}{c}\text { Predominant } \\
\text { gender }\end{array}$ & $\begin{array}{c}\text { Predominant } \\
\text { distribution }\end{array}$ \\
\hline 1 & Our study & $7.10 \%$ & $85.71 \%$ females & $16-32 \%$ \\
2 & Olubode & $17.43 \%$ & $18.81 \%$ males & $16 / 26-71 \%$ \\
3 & $\begin{array}{c}\text { O.Falomo } \\
\text { Syed Sadatullah }\end{array}$ & $44.93 \%$ & & $16 / 26-83 \%$ \\
\hline
\end{tabular}

In the present study the prevalence of cusp of carabelli was $7 \%$, while in other studies like Olubode O. Falomo's study showed the prevalence to be $17.43 \%$ and in Syed Sadatullahstudy to be $44.93 \%$.
In the present study the predominant gender was females $(85.71 \%)$. But this was in contradiction to the study done by Olubode O. Falomowhere males $(85.71 \%)$ were the predominant gender.

In the present study the predominant distribution was unilateral $16(32 \%)$. But this was in contradiction to the study done by Olubode O. Falomo and Syed Sadatullahwhere the prevalent distribution was $16 / 26(71 \%)$ and $16 / 26(83 \%)$ respectively.

\section{CONCLUSION}

According to present study the prevalence of cusp of carabelliin Indian population was found to be less than in the Nigerian population and Saudi Arabian population. The variation may be due to ethnic and regional differences. More number of samples are needed for better evaluation and comparison.

\section{References}

1. Olubode O. Falomo. The cusp of carabelli-frequency, distribution, size and clinical significance in Nigeria. wAJM.2002.vol 20:21 No:4.

2. Syed Sadatullah. The prevalence of fifth cusp in the upper molars in Saudi Arabian school students. J.morphol.2012.30(2):757-760.

3. Salako, N. O. \& Bello, L. L. Prevalence of the Carabelli trait in Saudi Arabian children. Odontostomatol. Trop., 21(84):11-4, 1998.4.Shethri, S. The prevalence of Carabelli cusp in selected Saudi population. J. King Saud. Univ., 2(1-2):13-6, 2011.

4. Sousa, E. M. D.; Carvalho, L. F. P. C. \& Pereira, L. L. Prevalencia do tuberculo de Carabelli no premeiro molar superior. Rev. Fac. Odontol. Odonto. Univ. Fed Bhia, 20:6-10, 2000.

5. Townsend, G. C. \& Brown, T. The Carabelli trait in Australia Aboriginal dentition. Arch. Oral Biol., 26(10):809-14, 1981.

\section{How to cite this article:}

Dhanalakshmi S and Don K. R (2017) ' Cusp Ofcarabelli- Frequency, Distribution, Size And Clinical Significance', International Journal of Current Advanced Research, 06(04), pp. 3042-3044.

DOI: http://dx.doi.org/10.24327/ijcar.2017.3044.0175 